EWA KOROL ${ }^{2}$

Instytut Psychologii

Uniwersytet Marii Curie-Skłodowskiej w Lublinie

\title{
WZORCE FUNKCJONOWANIA RODZINY POCHODZENIA A INTELIGENCJA EMOCJONALNA MŁODYCH DOROSŁYCH
}

\section{STRESZCZENIE}

W artykule opisano badania dotyczące związku między poziomem ogólnej inteligencji emocjonalnej oraz poszczególnych jej składników u młodych dorosłych a wzorcami ich funkcjonowania w rodzinach pochodzenia. Analizą metodologiczną objęto wyniki uzyskane od 121 osób (72 kobiet i 49 mężczyzn) w wieku 21-26 lat. Dla potrzeb niniejszej pracy rodzina rozumiana jest zgodnie z ujęciem systemowym, inteligencja emocjonalna zaś zgodnie z modelem zdolnościowym. W związku z tym w badaniu wykorzystano następujące metody badawcze: Skale oceny rodziny (SOR), Popularny kwestionariusz inteligencji emocjonalnej (PKIE) oraz ankietę własną. Jak pokazały wyniki, istnieją zależności między określonymi wzorcami funkcjonowania rodziny pochodzenia młodych dorosłych a ich ogólnym poziomem inteligencji emocjonalnej oraz jej poszczególnymi zdolnościami.

Słowa kluczowe: inteligencja emocjonalna, wzorce funkcjonowania rodziny, znaczenie rodziny pochodzenia

\section{PATTERNS OF FUNCTIONING OF THE FAMILY OF ORIGIN AND THE EMOTIONAL INTELLIGENCE OF YOUNG ADULTS}

\begin{abstract}
This article describes the research concerning the connection between the level of general emotional intelligence, and its individual components, among young adults and the model of functioning of their family background. The analysis was conducted on the sample of 121 individuals, 72 women and 49 men, aged 21-26. Within the context of this work a family is understood in accordance with a systemic perspective and EI in accordance with the ability model. The following methods have been used in the study: Polish adaptation FACES-IV (Flexibility and Cohesion Evaluation Scales) David H. Olson's, Popular Questionnaire of Emotional Intelligence and own survey. The article contains the discussion of the results, which shows that there is a statistically significant relation between the specific model of family background of young adults and their general level of EI with its individual abilities.
\end{abstract}

Keywords: emotional intelligence, the specific model of family functioning, the importance of family of background

\footnotetext{
²Adres do korespondencji: ewakrl@o2.pl
} 


\section{WPROWADZENIE}

Punktem wyjścia podjętych rozważań i badań jest założenie, że inteligencja emocjonalna młodych dorosłych wiąże się z wzorcami charakteryzującymi ich rodziny pochodzenia. Obecnie, na podstawie licznych badań empirycznych, nikt już nie kwestionuje znaczenia środowiska rodzinnego dla rozwoju człowieka. Również inteligencji emocjonalnej naukowcy poświęcili w ciągu ostatnich ponad 20 lat wiele uwagi, koncentrując się jednak raczej na jej znaczeniu aniżeli na jej uwarunkowaniach (por. Knopp, 2010). Niemniej jednak już twórcy koncepcji inteligencji emocjonalnej (Mayer, Salovey, 1999), postulując, że rozwija się ona przede wszystkim w wyniku aktywności własnej jednostki, sugerowali szczególne zwrócenie uwagi na dotychczasowe doświadczenia człowieka, zwłaszcza te zainicjowane w środowisku rodzinnym. W środowisku, w którym ludzie po raz pierwszy zostają wprowadzeni w świat emocji (Bradshaw, 1994).

Konstrukt inteligencji emocjonalnej pojawił się w efekcie konkluzji, że gromadzone przez lata dane z badań empirycznych dowiodły, że nie wszystkie problemy udaje się ludziom rozwiązać wyłącznie dzięki inteligencji poznawczej. W związku z tym, próbując przewidzieć funkcjonowanie człowieka, zaczęto brać pod uwagę również jego pozostałe predyspozycje indywidualne (Matczak, Jaworowska, 2001; Matczak, 2007). I tak na początku lat 90. John. D. Mayer i Peter Salovey (1999) wprowadzili pojęcie inteligencji emocjonalnej (IE) i jako pierwsi zdefiniowali i opisali jej strukturę oraz możliwości pomiaru. I chociaż współcześnie w psychologii mówi się na ogół o trzech modelach IE: modelu Mayera i Saloveya, modelu Golemana oraz modelu Bar-Ona, to koncepcja Saloveya i Mayera (1999) jako jedyna została uznana za model zdolnościowy i naukowy zarazem (IE jako zbiór zdolności emocjonalnych). Pozostałe dwie koncepcje są określane mianem modeli mieszanych, w zakres pojęcia inteligencji emocjonalnej zostały bowiem włączone także cechy osobowości, kompetencje społeczne czy też właściwości motywacyjne jednostki, które znacznie wykraczają poza predyspozycje sprawnościowe (Bar-On, 2006; Goleman, 1995; Śmieja, Orzechowski, 2008).

Koncepcja Saloveya i Mayera (1999) uwzględnia cztery grupy zdolności składające się na globalny poziom inteligencji emocjonalnej, które zostały scharakteryzowane w porządku wzrastającej złożoności. Podstawowy komponent to zdolność do wyrażania i spostrzegania emocji, zarówno u siebie, jak i u innych (w tym przyswajanie sobie słownika emocjonalnego, rozróżnianie adekwatnych i nieadekwatnych, szczerych i nieszczerych wyrazów uczuć, dostrzeganie emocjonalnego wyrazu dzieł sztuki). Drugi obszar to emocjonalne wspomaganie myślenia, a więc wykorzystanie emocji dla efektywniejszego rozumowania, rozwiązywania problemów czy podejmowania decyzji. Kolejnym komponentem IE jest rozumienie i analizowanie emocji (zarówno własnych, jak i cudzych), a także powstawanie wiedzy na ich temat. Umożliwia to jednostce rozumienie zarówno prostych, jak i złożonych lub sprzecznych stanów emocjonalnych oraz dostrzeżenie następstw określonych emocji wraz z możliwymi zmianami w ich przebiegu, co sprzyja regulowaniu emocji. Świadome kierowanie emocjami, jako ostatni aspekt IE, służy osobistemu zrozumieniu i rozwojowi (Nęcka, 2003).

Badania nad korelatami inteligencji emocjonalnej potwierdzają, że wiąże się ona $\mathrm{z}$ wieloma aspektami funkcjonowania człowieka: dobrostanem psychofizycznym jednostki (Schutte, Malouff, 2011), przystosowaniem i funkcjonowaniem społecznym (Martowska, 2012; Saarni, 1999), trwałością związku partnerskiego (Fitness, 2001) i satysfakcją z niego 
(Kriegelewicz, 2005), rzadszym korzystaniem z pomocy psychoterapeutów (Palmer, Donaldson, Stough, 2002), sukcesami akademickimi (Bar-On, 2006) oraz zawodowymi (Cherniss, 2000).

Można sądzić, że rozwój zdolności składających się na inteligencję emocjonalną dokonuje się w środowisku rodzinnym (Bradshaw, 1994). Rozwój emocjonalny dziecka zależy bowiem od klimatu emocjonalnego rodziny, a zatem zdolności wchodzące w skład inteligencji emocjonalnej, np.: zdolności do różnicowania reakcji emocjonalnych, intencjonalnego komunikowania emocji i rozumienia ekspresji emocjonalnej u innych rozwijają się również, a we wczesnym okresie rozwoju dziecka - przede wszystkim, dzięki rodzinie (Leopold, 2000; Suchańska, 1999). Rzeczywiście, wyniki badań potwierdzają znaczenie środowiska rodzinnego dla rozwoju inteligencji emocjonalnej, kompetencji emocjonalnych i dojrzałości uczuciowej dzieci. Z badań wynika, że troska i pozytywny emocjonalny klimat w rodzinie sprzyja przyswajaniu emocjonalnej wiedzy (Bennet, Bendersky, Lewis, 2005), rozumieniu emocji (Dunn, Brown, 1994) i regulacji emocji przez dzieci (Eisenberg, Cumberland, Spinrad, 1998). Kiedy rodzic wykazuje postawę pełną ciepła i pozytywnego nastawienia, wówczas dzieci doświadczają mniej złości i rzadziej przejawiają agresywne zachowania, wynikające $\mathrm{z}$ odczuwania silnych, przykrych emocji (Eisenberg, 2005). Kowalik-Olubińska (2005) potwierdziła dodatni związek między bezpiecznym stylem przywiązania i zdrowiem emocjonalnym jednostki. Ponadto dowiedziono, że otwartość rodziców na rozmowy z dzieckiem o emocjach jest związana dodatnio z jego inteligencją emocjonalną (Piekarska, 2009).

Badania obrazują również znaczenie stylów rodzicielskich dla rozwoju emocjonalnego. Mianowicie sposób wychowania bliski stylowi demokratycznemu i tolerancyjnemu sprzyja wysokiemu poziomowi inteligencji emocjonalnej, autorytarny zaś i dyktatorski - wręcz przeciwnie (Knopp, 2010; Nastas, Sala, 2011; Martowska, 2009; Manuel, 2002). Oznacza to, że styl rodzicielski charakteryzujący się wsparciem, wrażliwością, zainteresowaniem ze strony rodziców jest dodatnio związany ze zdolnością młodych osób do wyrażania swoich emocji, zarządzania nimi i braniem za nie odpowiedzialności, a także ze zdolnością identyfikacji i akceptacji uczuć innych. Co więcej, badania Guastello i Guastello (2003) wykazały, że poziom inteligencji emocjonalnej matek dodatnio koreluje z poziomem inteligencji emocjonalnej ich dorosłych synów i córek. O tym, jak istotną rolę odgrywa prawidłowo funkcjonująca rodzina, świadczą również badania rodzin z problemami. Badania Hodgins i Belch (2000) obrazują, że dzieci, które były świadkami przemocy w rodzinie oraz patologicznego sposobu wyrażania i rozładowywania emocji, same mają problem z ekspresją emocjonalną, która staje się niejasna i trudna do odczytania.

W świetle zaprezentowanych danych $\mathrm{z}$ literatury przedmiotu na temat wychowawczych uwarunkowań inteligencji emocjonalnej u dzieci można sądzić, że interakcje wewnątrzrodzinne (ustanowione przez wzajemne wzory funkcjonowania) stanowią o jakości życia jednostki (Grzesiuk, Jakubowska, 2005), wpływają na stopień zaspokojenia jej potrzeb fizycznych i psychicznych, a w konsekwencji na sposób ukształtowania się jej osobowości - zwłaszcza sfery uczuciowo-emocjonalnej (Cudak, 2007; Jarosz, Wysocka, 2006). Dlatego też wzorce funkcjonowania rodziny uznano za istotny predyktor inteligencji emocjonalnej młodych dorosłych. Za takim założeniem przemawiają wyniki badań nad uwarunkowaniami rozwoju kompetencji emocjonalnych, dojrzałości uczuciowej, ale przede wszystkim inteligencji emocjonalnej (Salovey, Mayer, 1999; Mahasneh, Al-Zoubi, Batayenh, 2014). 
Jako koncepcję podstawową rozumienia związków między funkcjonowaniem rodziny, pochodzenia a zdrowiem i satysfakcjonującym funkcjonowaniem jej członków przyjęto systemowe ujęcie rodziny (Bradshaw, 1994). W literaturze istnieją różne modele ułatwiające ocenę systemu danej rodziny (Kaleta, 2011). Dla niniejszej pracy szczególnie istotny jest Model Kołowy Olsona (Olson, Gorall, 2003). W modelu wyróżnia się dwa wymiary pierwotne: spójność i elastyczność oraz jako pomocnicze: komunikację i zadowolenie z życia rodzinnego. Różne nasilenie każdej z trzech pierwszych cech (spójności, elastyczności i komunikacji) oraz ich wzajemne konfiguracje sprawiają, że każdy system rodzinny jest niepowtarzalny, ich funkcjonowanie zaś osiąga różne poziomy prawidłowości lub zaburzeń. Spójność świadczy o więzi emocjonalnej między członkami rodziny, a jej wskaźnikami są m.in.: ilość wspólnie spędzanego czasu, wspólni przyjaciele, zainteresowania, interesy, jakość granic wewnętrznych i zewnętrznych, działające koalicje czy stopień konsultowania $\mathrm{z}$ innymi domownikami podejmowanych decyzji. Jako elastyczność należy rozumieć ilość, jakość oraz stopień rzeczywistych zmian zachodzących w systemie, z którymi jego członkowie potrafią sobie faktycznie poradzić. Ocena elastyczności odnosi się do tego, jak rodzina reorganizuje swoją strukturę, zarówno w odpowiedzi na wewnętrzne żądania, jak i zewnętrzne wydarzenia. Dla prawidłowego funkcjonowania system potrzebuje zarówno stałości, jak i zmiany (de Barbaro, 1999). Trzeci, pomocniczy wymiar - komunikację, można najogólniej ująć jako dominujący wzorzec porozumiewania się wewnątrzrodzinnego, w związku z czym jest ona uznawana za wiarygodny wskaźnik funkcjonowania interpersonalnego danego systemu rodzinnego oraz panujących w nim stosunków (Harwas-Napierała, 2006). Zmienną opisującą rodzinę jest również satysfakcja, która, jak sama nazwa wskazuje, określa stopień, w jakim domownicy czują się ze sobą szczęśliwi i spełnieni (Olson, Gorall, 2003; Olson, 2011). Przyjmuje się, że zrównoważone poziomy spójności i elastyczności oraz jak najwyższa jakość komunikacji są najkorzystniejsze dla zdrowego funkcjonowania systemu rodzinnego, podczas gdy poziomy niezrównoważone (skrajne - bardzo niskie i bardzo wysokie wyniki) wraz z niską efektywnością komunikacji wiążą się z problemami w funkcjonowaniu systemu (Olson, 2011).

Biorąc pod uwagę powyższe rozważania i dane empiryczne, za uzasadnione uznano podjęcie badań, których celem będzie odpowiedź na pytanie: czy istnieje i na czym polega zależność między wzorcami funkcjonowania rodziny pochodzenia a inteligencją emocjonalną (wraz z uwzględnieniem składających się na nią komponentów) młodych dorosłych. Przytoczone powyżej przesłanki teoretyczne i wyniki badań dają podstawę do przyjęcia następującej hipotezy:

Istnieje zależność między określonymi wzorcami funkcjonowania rodziny pochodzenia młodych dorosłych a ich ogólnym poziomem inteligencji emocjonalnej (oraz poziomem poszczególnych zdolności wchodzących w skład inteligencji emocjonalnej):

- Istnieje dodatnia zależność między zrównoważoną spójnością a poziomem ogólnej inteligencji emocjonalnej młodych dorosłych (oraz poziomem poszczególnych zdolności wchodzących w skład inteligencji emocjonalnej);

- Istnieje dodatnia zależność między zrównoważoną elastycznością a poziomem ogólnej inteligencji emocjonalnej młodych dorosłych (oraz poziomem poszczególnych zdolności wchodzących w skład inteligencji emocjonalnej); 
- Istnieje dodatnia zależność między efektywną komunikacją a poziomem ogólnej inteligencji emocjonalnej młodych dorosłych (oraz poziomem poszczególnych zdolności wchodzących w skład inteligencji emocjonalnej;

- Istnieje dodatnia zależność między satysfakcją z relacji rodzinnych a poziomem ogólnej inteligencji emocjonalnej młodych dorosłych (oraz poziomem poszczególnych zdolności wchodzących w skład inteligencji emocjonalnej);

- Istnieje ujemna zależność między niezwiązaniem a poziomem ogólnej inteligencji emocjonalnej młodych dorosłych (oraz poziomem poszczególnych zdolności wchodzących w skład inteligencji emocjonalnej);

- Istnieje ujemna zależność między splątaniem a poziomem ogólnej inteligencji emocjonalnej młodych dorosłych (oraz poziomem poszczególnych zdolności wchodzących w skład inteligencji emocjonalnej);

- Istnieje ujemna zależność między sztywnością a poziomem ogólnej inteligencji emocjonalnej młodych dorosłych (oraz poziomem poszczególnych zdolności wchodzących w skład inteligencji emocjonalnej);

- Istnieje ujemna zależność pomiędzy chaotycznością a poziomem ogólnej inteligencji emocjonalnej młodych dorosłych (oraz poziomem poszczególnych zdolności wchodzących w skład inteligencji emocjonalnej).

\section{METODA}

\section{OSOBY BADANE}

Biorąc pod uwagę badania potwierdzające, że inteligencja emocjonalna wzrasta wraz z wiekiem i wykształceniem, grupę osób badanych zawężono do osób z wykształceniem co najmniej średnim, ale nieprzekraczającym wykształcenia wyższego. Ponadto, ze względu na postawiony sobie cel, z badań wykluczono osoby studiujące psychologię bądź biorące kiedykolwiek udział w warsztatach poświęconych lepszemu rozumieniu emocji (wyniki tych osób nie zostały poddane empirycznej analizie). W związku z tym ostateczną analizą wyników objęto 121 młodych dorosłych: 72 kobiet (60\%) i 49 mężczyzn (40\%) w wieku 21-26 lat $(M=23,02$ lata; $S D=1,291)$. Spośród 121 osób, 75 osób (62\%) stanowili studenci, 46 osób (38\%) natomiast to osoby niestudiujące, aktualnie pracujące lub szukające pracy.

\section{SPOSÓB PRZEPROWADZANIA BADAŃ}

Badania miały charakter indywidualny. Badani byli informowani o charakterze i celu badań, a także o anonimowości. Każda z osób, która zgodziła się na udział w badaniu, otrzymywała narzędzia badawcze ułożone w następującej kolejności: Skale oceny rodziny (SOR) w adaptacji Andrzeja Margasińskiego (2009), Popularny kwestionariusz inteligencji emocjonalnej (PKIE) autorstwa Aleksandry Jaworowskiej i Anny Matczak (2009) oraz autorską ankietę własną. Czas badania wynosił od 15 do 80 minut.

\section{NARZĘDZIA}

Dwiema głównymi zmiennymi uwzględnionymi w badaniach są wzorzec funkcjonowania rodziny pochodzenia oraz inteligencja emocjonalna. Do pomiaru pierwszej z nich zastosowano SOR, będący polską adaptacją FACES-IV Davida H. Olsona (2011). Struktura kwestionariusza jest zgodna z modelem Olsona. SOR składa się z 62 twierdzeń, do których 
badany ustosunkowuje się w skali pięciostopniowej. Twierdzenia te tworzą osiem skal. Sześć z nich dotyczy dwu wymiarów funkcjonowania rodziny - spójności i elastyczności; skale te to: zrównoważona spójność (ZS), niezwiązanie (N), splątanie (SP), zrównoważona elastyczność (ZE), sztywność (SZ), chaotyczność (CH). Dwie pozostałe (dodatkowe) skale mierzą komunikację $(\mathrm{K})$ oraz zadowolenie z życia rodzinnego $(\mathrm{Z})$. Wzorce funkcjonowania rodziny są analizowane przez pryzmat właśnie tych ośmiu skal. Wysoka rzetelność oraz trafność testu przemawiają za wykorzystaniem tej metody w badaniach naukowych.

Druga zmienna, jaką jest inteligencja emocjonalna, została zmierzona za pomocą PKIE (Jaworowska, Matczak, 2009). Kwestionariusz ten oparty jest na zdolnościowym modelu inteligencji emocjonalnej wg Saloveya i Mayera. Składa się z 94 pozycji o charakterze samoopisowym. Osoba badana ocenia każdorazowo na skali pięciopunktowej stopień, w jakim dane stwierdzenie odnosi się do niej samej. Dzięki podanym odpowiedziom uzyskujemy jeden ogólny wynik (WO) oraz wyniki dodatkowe w czterech skalach: akceptowania, wyrażania i wykorzystywania własnych emocji w działaniu (AKC); empatii, czyli rozumienia i rozpoznawania emocji innych ludzi (EMP); kontroli, także poznawczej, nad własnymi emocjami (KON); rozumienia i uświadamiania sobie własnych emocji (ROZ). Dzięki potwierdzonej trafności i rzetelności kwestionariusza może on być stosowany z powodzeniem do celów badawczych.

\section{WYNIKI BADAŃ}

W celu weryfikacji hipotezy zastosowano współczynnik korelacji $r$ Pearsona (spełniony wymóg normalnego rozkładu zmiennych) do określenia związku między wymiarami funkcjonowania rodziny a inteligencją emocjonalną młodych dorosłych. Wyniki analizy korelacji wskazują na istnienie interesujących związków z punktu widzenia celu badawczego (tabela 1), zwłaszcza na szczególne znaczenie zrównoważonej spójności i zrównoważonej elastyczności, komunikacji wewnątrzrodzinnej oraz zadowolenia z życia rodzinnego. To właśnie z nimi, w sposób silny lub umiarkowany, korelował dodatnio poziom ogólnej inteligencji emocjonalnej, a także zdolności do akceptacji i empatii. Ogólna inteligencja emocjonalna, wraz z tworzącymi ją komponentami, również istotnie koreluje z niezwiązaniem oraz chaotycznością, przy czym jest to korelacja ujemna. Najmniej istotnym wzorcem okazała się sztywność. Jako jedyna nie koreluje w sposób istotny z inteligencją emocjonalną.

Tabela 1

Wymiary funkcjonowania rodziny a inteligencja emocjonalna - analiza korelacji mierzonej współczynnikiem r Pearsona $(N=121)$

\begin{tabular}{lccccc}
\hline & \multicolumn{5}{c}{ PKIE } \\
\hline SOR & WO & AKC & EMP & KON & ROZ \\
\hline ZS & $0,77^{\star *}$ & $0,70^{* *}$ & $0,65^{* *}$ & $0,36^{* *}$ & $0,38^{\star *}$ \\
ZE & $0,67^{\star *}$ & $0,62^{* *}$ & $0,63^{* *}$ & $0,22^{*}$ & $0,29^{* *}$ \\
N & $-0,75^{\star *}$ & $-0,66^{\star *}$ & $-0,62^{* *}$ & $-0,34^{* *}$ & $-0,43^{\star *}$ \\
S & $-0,36^{* *}$ & $-0,29^{* *}$ & $-0,16$ & $-0,24^{* *}$ & $-0,30^{* *}$ \\
SZ & 0,17 & 0,15 & 0,17 & $-0,05$ & 0,08
\end{tabular}




\begin{tabular}{lccccc}
\hline & \multicolumn{5}{c}{ PKIE } \\
\hline SOR & WO & AKC & EMP & KON & ROZ \\
\hline $\mathrm{CH}$ & $-0,48^{* *}$ & $-0,38^{* *}$ & $-0,46^{* *}$ & $-0,36^{* *}$ & $-0,31^{* *}$ \\
$\mathrm{~K}$ & $0,76^{* *}$ & $0,68^{* *}$ & $0,70^{* *}$ & $0,29^{* *}$ & $0,41^{\star *}$ \\
$\mathrm{Z}$ & $0,74^{* *}$ & $0,67^{* *}$ & $0,76^{* *}$ & $0,27^{* *}$ & $0,42^{* *}$ \\
\hline
\end{tabular}

Adnotacja. SOR - Skale oceny rodziny (ZS - Zrównoważona spójność; ZE - Zrównoważona elastyczność; N - Niezwiązanie; S - Splątanie; SZ - Sztywność; CH - Chaotyczność; K - Komunikacja; Z - Zadowolenie); PKIE - Popularny kwestionariusz inteligencji emocjonalnej (WO - wynik ogólny; AKC - Akceptacja; EMP - Empatia; KON - Kontrola; ROZ - Rozumienie).

${ }^{\star} p<0,05 ;{ }^{* *} p<0,01$.

Uzyskane istotne korelacje między skalami SOR a skalami PKIE zainicjowały dalszą, dodatkową eksplorację uzyskanych wyników. W tym celu sięgnięto do wielozmiennowej analizy regresji metodą krokową (tabele 2-6), umożliwiającą przewidywanie wartości inteligencji emocjonalnej na podstawie zastosowanych predyktorów (inaczej mówiąc, pokazującą, w jakim stopniu wzorce funkcjonowania rodziny wyjaśniają IE). Jak się okazało, najistotniejszymi predyktorami ogólnej inteligencji emocjonalnej (tabela 2) okazały się trzy wymiary funkcjonowania życia rodzinnego: zadowolenie, zrównoważona spójność oraz komunikacja. Zadowolenie z życia rodzinnego wyjaśnia 63\% wariancji, w połączeniu z kolei ze zrównoważoną spójnością i satysfakcjonującą komunikacją wyjaśnia 71\% zmienności wyników uzyskiwanych przez badanych w kwestionariuszu PKIE. Oznacza to, że tylko 29\% wariancji zmiennej zależnej (jaką jest ogólna IE) jest wyjaśnione innymi czynnikami.

Tabela 2

Regresja wielozmiennowa krokowa. Zmienna zależna: ogólna inteligencja emocjonalna, zmienne niezależne: wymiary funkcjonowania rodziny pochodzenia $(N=121)$

\begin{tabular}{lllll}
\hline Predyktory & $\beta$ & $R$ & $R^{2}$ & $F(3,117)$ \\
\hline Zadowolenie & 0,79 & 0,79 & 0,63 & $203,04^{* * *}$ \\
\hline Zadowolenie & 0,49 & 0,84 & 0,71 & $141,74^{* * *}$ \\
Zrównoważona spójność & 0,41 & & & \\
\hline Zadowolenie & 0,36 & 0,85 & 0,72 & $98,68^{*}$ \\
Zrównoważona spójność & 0,37 & & & \\
Komunikacja & 0,20 & & & \\
\hline
\end{tabular}

${ }^{\star} p<0,05 ;{ }^{* * *} p<0,001$.

Zrównoważona spójność oraz komunikacja okazały się również istotnymi czynnikami wyjaśniającymi komponent inteligencji emocjonalnej, jakim jest akceptacja. O ile zrównoważona spójność wyjaśniła $48 \%$ wariancji akceptacji, o tyle w połączeniu z prawidłową komunikacją wyjaśnia już 55\% zmienności zmiennej, jaką jest akceptacja (tabela 3). 
Tabela 3

Regresja wielozmiennowa krokowa. Zmienna zależna: akceptacja, zmienne niezależne: wymiary funkcjonowania rodziny pochodzenia $(N=121)$

\begin{tabular}{lllll}
\hline Predyktory & $\beta$ & $R$ & $R^{2}$ & $F(2,118)$ \\
\hline Zrównoważona spójność & 0,70 & 0,70 & 0,48 & $113,30^{* * *}$ \\
\hline Zrównoważona spójność & 0,43 & 0,56 & 0,55 & $74,23^{* * *}$ \\
Komunikacja & 0,38 & & & \\
\hline
\end{tabular}

${ }^{* * *} p<0,001$.

Zrównoważona spójność wyjaśniła 18\% wariancji kontroli emocjonalnej (tabela 4).

Tabela 4

Regresja wielozmiennowa krokowa. Zmienna zależna: kontrola, zmienne niezależne: wymiary funkcjonowania rodziny pochodzenia $(N=121)$

\begin{tabular}{lllll}
\hline Predyktory & $\beta$ & $R$ & $R^{2}$ & $F(2,118)$ \\
\hline Zrównoważona spójność & 0,36 & 0,36 & 0,18 & $17,83^{\star * *}$ \\
\hline Zrównoważona spójność & 0,25 & 0,43 & 0,13 & $13,31^{* *}$ \\
Chaotyczność & $-0,25$ & & & \\
\hline
\end{tabular}

${ }^{* *} p<0,01 ;{ }^{* *} p<0,001$.

Zarówno zadowolenie, jak i zrównoważona spójność stanowią istotne predyktory empatii - 58\% wariancji zmiennej empatii jest wyjaśniane za pomocą zadowolenia z życia rodzinnego, zadowolenie i zrównoważona spójność wyjaśniają natomiast $60 \%$ wariancji empatii (tabela 5).

Tabela 5

Regresja wielozmiennowa krokowa. Zmienna zależna: empatia, zmienne niezależne: wymiary funkcjonowania rodziny pochodzenia $(N=121)$

\begin{tabular}{lllll}
\hline Predyktory & $\beta$ & $R$ & $R^{2}$ & $F(2,118)$ \\
\hline Zadowolenie & 0,76 & 0,76 & 0,58 & $167,79^{* * *}$ \\
\hline Zadowolenie & 0,62 & 0,78 & 0,60 & $89,30^{*}$ \\
Zrównoważona spójność & 0,19 & & & \\
\hline
\end{tabular}

${ }^{* * *} p<0,001 ;{ }^{*} p<0,05$.

Jeżeli chodzi o ostatni komponent inteligencji emocjonalnej - rozumienie emocji, jest on wyjaśniany w $18 \%$ przez niezwiązanie, w $22 \%$ zaś przez niezwiązanie oraz splątanie (tabela 6). 
Tabela 6

Regresja wielozmiennowa krokowa. Zmienna zależna: rozumienie, zmienne niezależne: wymiary funkcjonowania rodziny pochodzenia $(N=121)$

\begin{tabular}{lllll}
\hline Predyktory & $\beta$ & $R$ & $R^{2}$ & $F(2,118)$ \\
\hline Niezwiązanie & $-0,43$ & 0,43 & 0,18 & $26,50^{*}$ \\
\hline Niezwiązanie & $-0,37$ & 0,47 & 0,22 & $16,46^{*}$ \\
\hline Splątanie & $-0,20$ & & & \\
\hline
\end{tabular}

${ }^{\star} p<0,05$.

Uzyskane wyniki pokrywają się na ogół z wynikami uzyskanymi dzięki analizie korelacji $r$ Pearsona. Dane otrzymane dzięki analizie regresji obrazują, że niektóre wymiary życia rodzinnego są szczególnie istotne dla rozwoju inteligencji emocjonalnej.

\section{DYSKUSJA}

Jak pokazują wyniki niniejszych badań, szczególnie ważne dla inteligencji emocjonalnej okazały się: zrównoważona spójność, zrównoważona elastyczność, efektywna komunikacja oraz zadowolenie z życia rodzinnego. Wyniki te pozostają w zgodzie z dotychczasowymi rozważaniami i postawioną na ich podstawie hipotezą. Zrównoważona spójność, zrównoważona elastyczność, efektywna komunikacja oraz zadowolenie z życia rodzinnego okazały się dodatnio i silnie związane z ogólną inteligencją emocjonalną oraz z dwoma jej komponentami: akceptacją emocji i empatią.

Istotna statystycznie dodatnia zależność między zrównoważoną spójnością a inteligencją emocjonalną oznacza, że bliskie więzi emocjonalne, wspólnie spędzany czas, wspólne zainteresowania, istnienie półprzepuszczalnych granic, empatyczne, otwarte, wzajemne zaangażowanie w sprawy rodziny i jej domowników, przy jednoczesnym zachowaniu miejsca na przestrzeń prywatną sprzyjają akceptowaniu, wyrażaniu i wykorzystywaniu własnych emocji w działaniu oraz rozpoznawaniu i rozumieniu emocji u innych (Plopa, 2008; Suchańska, 1999). Niezwiązanie, czyli niedostateczny poziom bliskości emocjonalnej, koreluje natomiast silnie, ale ujemnie $\mathrm{z}$ inteligencją emocjonalną, a zwłaszcza $\mathrm{z}$ akceptacją emocji i empatią. W takich rodzinach rodzice ignorują dzieci, a tym samym ich przeżycia i uczucia. Pozostawiają je samym sobie, bez emocjonalnego wsparcia (Radochoński, 2003). Brak bliskości i płynącego z niej oparcia emocjonalnego prowadzi do zbyt szybkiego osiągnięcia dojrzałości przez dzieci, przez co stają się zagubione poznawczo-emocjonalnie (de Barbaro, M., 1999). W konsekwencji mogą mieć one m.in. problemy ze zdolnością do wyrażania emocji i braniem odpowiedzialności za swoje emocje, a także ze zdolnością do identyfikacji i akceptacji uczuć innych (Suchańska, 1999).

Z zaprezentowanych $\mathrm{w}$ tej pracy danych wynika również, że istnieje dodatni związek między zrównoważonym wymiarem elastyczności systemu rodzinnego a ogólną inteligencją emocjonalną, a także z jej dwiema składowymi: akceptacją emocji i empatią. Zrównoważona elastyczność oznacza zdolność rodziny do reagowania na zmiany, dostosowania się do nich przez wykształcanie nowych, skuteczniejszych strategii rozwiązywania problemów. W razie konieczności domownicy potrafią wymieniać się rolami bądź wspólnie, w sposób efektywny, je wypełniać (de Barbaro, M., 1999; Olson, Gorall, 2003). Taki sposób 
funkcjonowania rodziny umożliwia jej członkom konfrontowanie się z różnymi codziennymi sytuacjami nacechowanymi emocjonalnie. Dzięki temu mają oni możliwość nauki, zarówno wyrażania i wykorzystywania własnych emocji w działaniu, jak i akceptowania różnych emocji u siebie i u innych. Zdają sobie sprawę, że każda emocja niesie ze sobą określoną informację, a nie problem, co pozwala im na wyrażanie zarówno przyjemnych, jak i przykrych emocji. Jednocześnie, dzięki klarownym wymaganiom rodziców, osoby $\mathrm{z}$ takich rodzin potrafią przewidzieć, jakie emocje u innych wywoła ich zachowanie, aby w miarę możliwości dostosować się do sytuacji, kontekstu, okoliczności. Można zatem sądzić, że zrównoważona elastyczność prowadzi do zdobywania wiedzy emocjonalnej czy też wykształcenia się empatii (Perlman, Camras, Pelphery, 2008). Powyższe rozważania naprowadzają jednocześnie na możliwe źródła ujemnej korelacji między chaotycznością a inteligencją emocjonalną. Rodziny chaotyczne nie potrafią w sposób umiejętny reagować na zmiany, a więc w sposób, który dawałby im poczucie bezpieczeństwa, zapewniając jednocześnie możliwość otwartej eksploracji. Rodzice są zdystansowani wobec siebie oraz niekonsekwentni wobec dzieci, w sytuacjach bezsilności mogą natomiast sięgać po surowe, nieadekwatne kary (Field, 1999). Młodzi ludzie pochodzący z takich rodzin uczą się izolować od źródeł konfliktów i związanych z nimi emocji (Radochoński, 2003).

Zaprezentowane dane wykazały jednocześnie brak znaczącego związku między inteligencją emocjonalną a splątaniem i sztywnością. Co prawda, splątanie koreluje ujemnie z ogólnym poziomem inteligencji emocjonalnej oraz z rozumieniem emocji, ale jest to zależność słaba. Taki wynik może wskazywać na kompensacyjną rolę środowiska w kształtowaniu inteligencji emocjonalnej wśród młodych dorosłych pochodzących $\mathrm{z}$ rodzin ograniczających możliwości autonomii czy własnego zdania. Sprzyja to buntowaniu się (Olson, Gorall, 2006). Młodzi ludzie buntujący się przeciwko wzorcom rodzinnym są jednocześnie bardziej aktywni na innych polach społecznych, co może rekompensować ich potencjalnie niesprzyjające (dla rozwoju emocjonalnego) doświadczenia z domu rodzinnego. Oczywiście, wniosek ten, w świetle aktualnego stanu wiedzy, ma status hipotezy, wymagającej dalszej weryfikacji empirycznej.

Dla ogólnego poziomu inteligencji emocjonalnej, a także akceptacji emocji i empatii, znaczące okazały się również komunikacja i satysfakcja z życia rodzinnego. Jak zauważa Frydrychowicz (2003), w trakcie komunikacji nadawca przekazuje swój stosunek emocjonalny nie tylko do komunikowanych treści, lecz także do odbiorcy komunikatu. Już Bateson (1972) wskazywał, że każdy komunikat ma dwa aspekty: przedmiotowy i relacyjny, co oznacza, że definiuje on również relację między komunikującymi się. Jak zauważa natomiast Rostowska (2008), to właśnie komunikacja jest nieodłącznym elementem tego, by w odpowiedni sposób równoważone były intymność, bliskość, niezależność, autonomia czy sposoby rozwiązywania konfliktów. Dlatego poziom efektywności komunikacji możemy uznać za odzwierciedlenie więzi i klimatu emocjonalnego w rodzinie. To dzięki otwartym, serdecznym, spokojnym i szczerym dyskusjom mamy możliwość opowiadać o swoich aktualnych przeżyciach emocjonalnych, co może sprzyjać wykształceniu m.in. strategii rozumienia i rozpoznawania emocji u innych. Jak pokazują badania, otwartość rodziców na rozmowy z dzieckiem o emocjach jest związana dodatnio z jego inteligencją emocjonalną (Piekarska, 2009). Również wyniki innych badań potwierdzają, że zdolność komunikowania emocji stanowi istotną składową inteligencji emocjonalnej (Mayer, Salovey, Caruso, 2008). 
Z efektywną komunikacją wiąże się również satysfakcja z życia rodzinnego definiowana jako stopień, w jakim członkowie rodziny czują się ze sobą szczęśliwi i spełnieni. Badania potwierdzają, że prawidłowemu rozwojowi emocjonalnemu sprzyjają ciepło rodzicielskie, troska, pozytywny klimat emocjonalny (Bennett, Bendersky, Lewis, 2005), akceptacja dzieci przez rodziców (Bhatia, 2012). Kiedy rodzic wykazuje postawę pełną ciepła i serdecznego nastawienia, wówczas dzieci doświadczają mniej złości i rzadziej przejawiają agresywne zachowania, wynikające z odczuwania silnych, przykrych emocji (Eisenberg, 2005).

Warto zwrócić uwagę na jeszcze jeden aspekt. Zdolność do kontrolowania i rozumienia emocji, jeżeli korelowały z wzorcami funkcjonowania rodziny, to w sposób istotny, aczkolwiek niski. Próbując wyjaśnić ten wynik, warto zwrócić uwagę na podział inteligencji emocjonalnej dokonany przez Matczak (Jaworowska, Matczak, 2009). Zgodnie z nim wspomniane dwie zdolności stanowią rodzaj inteligencji emocjonalnej strategicznej, która charakteryzuje wysoki poziom kierowania emocjami i ich rozumienia. Być może, zdolność do intelektualnej obróbki zdolności emocjonalnych, w przeciwieństwie do otwartości na własne i cudze emocje, jest w większym stopniu uwarunkowana przez inne czynniki aniżeli rodzinę pochodzenia. Są to jednak przypuszczenia, wymagające dalszych badań.

Przeprowadzone badania własne pozwalają na stwierdzenie, że istnieje istotna zależność między określonymi wzorami funkcjonowania rodziny pochodzenia a inteligencją emocjonalną młodych dorosłych. Wyniki te potwierdzają przede wszystkim, że diagnozowanie systemu rodziny generacyjnej umożliwia lepsze zrozumienie emocjonalnego funkcjonowania jednostki. Jak bowiem pokazują niniejsze badania, doświadczenia z domu rodzinnego rzutują w sposób istotny na określone zdolności emocjonalne, nawet w życiu dorosłym. Należy również mieć na uwadze, że inteligencję emocjonalną można rozwijać przez całe życie, w wyniku aktywności własnej jednostki (Mayer i Salovey, 1999). Okres młodej dorosłości jest niewątpliwie dobrym momentem, aby spojrzeć z dystansu na rodzinę pochodzenia i wyciągnąć konstruktywne wnioski dla siebie. Na ogół to właśnie wtedy młodzi dorośli odchodzą z domu rodzinnego, chociaż nie założyli jeszcze własnej rodziny. Wówczas to od nich samych zależy, w jakim stopniu rozwiną swój potencjał emocjonalny i czy wyniosą dobrą lekcję z własnych doświadczeń.

\section{BIBLIOGRAFIA}

Bar-On, R. (2006). The Bar-On model of emotional-social intelligence (ESI) Psicothema, $18,1-28$.

Bennett, D. S., Bendersky, M., Lewis, M. (2005). Antecedents of emotion knowledge: Predictors of individual differences in young children. Cognition and Emotion, 49, 375-396.

Bhatia, G. (2012). A study of family relationship in relation to emotional intelligence of the students of secondary level. International Journal of Scientific and Research Publications, 2(12), 1-5.

Bradshaw, J. (1994). Zrozumieć rodzinę. Rewolucyjna droga odnalezienia samego siebie. Warszawa: Wydawnictwo Instytutu Psychologii Zdrowia i Trzeźwości.

Braun-Gałkowska, M. (2008). Psychologia domowa. Lublin: Wydawnictwo KUL. 
Cherniss, C. (2000). Emotional intelligence: What it is and why it matters? Psychology, 15, $1-14$.

Cudak, H. (2007). Znaczenie rodziny w rozwoju i wychowaniu małego dziecka. Warszawa: Polskie Towarzystwo Psychologiczne.

de Barbaro, M. (1999). Struktura rodziny. W: B. de Barbaro (red.), Wprowadzenie do systemowego rozumienia rodziny (s. 45-55). Kraków: Collegium Medicum UJ.

Dunn, J., Brown, J. (1994). Affect expression in the family, children's understanding of emotions, and their interactions with others. Merrill-Palmer Quarterly, 40, 120-137.

Eisenberg, N., Cumberland, A., Spinrad, T. L. (1998). Parental socialization of emotion. Psychological Inquiry, 9, 241-273.

Eisenberg, N., Zhou, Q., Spinrad, T. L., Valiente, C., Fabes, R. A., Liew, J. (2005). Relations among positive parenting, children's effortful control, and externalizing problems: A three-wave longitudinal study. Child Development, 76(5), 1055-1071.

Field, D. (1999). Osobowości rodzinne. Warszawa: Oficyna Wydawnicza: „Logos” (wyd. 2). Fitness, J. (2001). Emotional intelligence and intimate relationship. W: J. Ciarrochi, J. P. Forgas, J. D. Mayer (red.), Emotional intelligence in everyday life. A scientific inquiry (s. 98-112). Philadelphia: Psychology Press.

Frydrychowicz, S. (2003). Komunikacja interpersonalna w rodzinie a rozwój dorosłych. W: B. Harwas-Napierała (red.), Rodzina a rozwój człowieka dorosłego (s. 101-122). Poznań: Wydawnictwo Naukowe: UAM.

Goleman, D. (1995). Inteligencja emocjonalna. Poznań: Media Rodzina.

Grzesiuk, L., Jakubowska, U. (2005). Terapia systemowa. W: L. Grzesiuk (red.), Psychoterapia. Teoria (s. 189-197). Warszawa: ENETEIA.

Guastello, D. D., Guastello, S. J. (2003). Androgyny, gender role behavior and emotional intelligence among college students and their parents. Sex Roles: A Journal of Research, 49, 663-673.

Harwas-Napierała, B. (2006). Komunikacja interpersonalna i jej kształtowanie jako istotny wymiar jakości życia rodzinnego. W: T. Rostowska (red.), Jakość życia rodzinnego. Wybrane zagadnienia (s. 29-42). Łódź: WSI.

Hodgins, H. S., Belch, C. (2000). Interparental violence and nonverbal abilities. Journal of Nonverbal Behavior, 24, 3-24.

Jarosz, E., Wysocka, E. (2006). Diagnoza psychopedagogiczna. Podstawowe problemy i rozwiązania. Warszawa: Wydawnictwo Akademickie Żak.

Kaleta, K. (2011). Rodzinne uwarunkowania społecznego funkcjonowania jednostek w świetle teorii Minuchina i Bowena. Roczniki Psychologiczne, 14, 141-158.

Knopp, K. A. (2010). Inteligencja emocjonalna oraz możliwości jej rozwijania u dzieci i młodzieży. Warszawa: Wydawnictwo Uniwersytetu Kardynała Stefana Wyszyńskiego.

Kowalik-Olubińska, M. (2005). Społeczno-edukacyjne konteksty rozwoju inteligencji emocjonalnej dziecka. Psychologia Rozwojowa, 10(1), 19-28.

Kriegelewicz, O. (2005). Inteligencja emocjonalna a zadowolenie ze związków i strategie rozwiązywania konfliktów małżeńskich. Przegląd Psychologiczny, 48(4), 431-452.

Leopold, M. A. (2000). Życie rodzinne a kompetencje emocjonalne dziecka. Edukacja i Dialog, 4, 15-20.

Manuel, M. P. (2002). Parental inducement of emotional intelligence. Imagination, Cognition Personality, 18(1), 3-23. 
Margasiński, A. (2009). Skale Oceny Rodziny. Polska adaptacja FACES IV Davida H. Olsona. Warszawa: Pracownia Testów Psychologicznych.

Martowska, K. (2009). Inteligencja emocjonalna licealistów a oddziaływania wychowawcze rodziców. Ruch Pedagogiczny, 3/4, 55-69.

Martowska, K. (2012). Psychologiczne uwarunkowania kompetencji społecznych. Warszawa: Liberi Libri.

Maruszewski, T., Ścigała, E. (1998). Emocje, aleksytymia, poznanie. Poznań: Wydawnictwo Fundacji Humaniora.

Matczak, A. (2007). Poznaj swoje emocje. Psychologia w Szkole, 4, 25-32.

Matczak, A., Jaworowska, A. (2001). Kwestionariusz Inteligencji Emocjonalnej INTE. Warszawa: Pracownia Testów Psychologicznych.

Matczak, A., Jaworowska, A. (2009). Popularny Kwestionariusz Inteligencji Emocjonalnej PKIE. Warszawa: Pracownia Testów Psychologicznych.

Mayer, J. D., Salovey, P. (1999). Czym jest inteligencja emocjonalna? W: P. Salovey, D. J. Sluyter (red.), Rozwój emocjonalny a inteligencja emocjonalna (s. 21-69). Poznań: Dom Wydawniczy Rebis.

Mayer, J. D., Salovey, P., Caruso, D. (2008). Emotional intelligence: new ability or eclectic traits? American Psychologist, 63, 503-517.

Morris, A. S., Silk, J. S., Steinberg, L., Myers, S. S, Robinson, L. R. (2007). The role of the family context in the development of emotion regulation. Social Development, 16(2), 361-388.

Nastas, L. E., Sala, K. (2011). Adolescents' emotional intelligence and parental styles. Procedia. Social and Behavioral Sciences, 33, 478-482

Nęcka, E. (2003). Inteligencja. Geneza. Struktura. Funkcje. Gdańsk: GWP.

Nixon, C., Watson, A. (1999). Adolescence: The mediating and moderating roles of self-efficacy beliefs. Merrill-Palmer Quarterly, 47(2), 165-187.

Olson, D. H., Gorall, D. (2003). Circumplex model of marital and family systems. W: F. Walsh (red.), Normal Family Processes (wyd. 3, s. 514-547). New York: Guilford.

Olson, D. H. (2006). FACES IV and The Circumplex Model. Minnesota: Life Innovations. [online], [Dostęp: 24.02.2015].

Olson, D. H. (2011). FACES IV and The Circumplex Model: validation study. Journal of Marital \& Family Therapy, 3(1), 64-80.

Palmer, B., Donaldson, K., Stough, C. (2002). Emotional intelligence and life satisfaction. Personality and Individual Differences, 33 (7), 1091-1100.

Pearson, E., Rao, N. (2003). Socialization goals, parenting practices, and peer competence in Chinese and English preschoolers. Early Childhood Development and Care, 173, 131-146.

Perlman, S. B., Camras, L. A., Pelphery, K. A. (2008). Physiology and functioning parent's vagal tone, emotion socialization, and children's emotion knowledge. Experimental Child Psychology, 100(4), 308-315.

Piekarska, J. (2009). The role of personality and child-parent dialogue in the development of emotional competence. W: A. Matczak (red.), Determinants of social and emotional competencies (s. 67-86). Warszawa: Wydawnictwo UKSW.

Plopa, M. (2008). Psychologia rodziny. Teoria i badania. Elbląg: Wydawnictwo Naukowe EUH-E. 
Radochoński, M. (2003). Rodzina dysfunkcjonalna a zdrowie psychiczne i somatyczne jednostki. W: B. Harwas-Napierała (red.), Rodzina a rozwój człowieka dorosłego (s. 149-185). Poznań: Wydawnictwo Naukowe: UAM.

Rostowska, T. (2008). Małżeństwo, rodzina, praca a jakość życia. Kraków: Wydawnictwo Impuls.

Saarni, C. (1999). Kompetencja emocjonalna i samoregulacja w dzieciństwie. W: P. Salovey, D. J. Sluyter (red.), Rozwój emocjonalny a inteligencja emocjonalna (s. 75-125). Poznań: Rebis.

Schutte, N. S., Malouff, J. M. (2011). Emotional intelligence mediates the relationship between mindfulness and subjective well-being. Personality and Individual Differences, 50, 1116-1119.

Suchańska, A. (1999). Wprowadzenie do wydania polskiego. W: P. Salovey, D. J. Sluyter (red.), Rozwój emocjonalny a inteligencja emocjonalna (s. 20-21). Poznań: Rebis.

Śmieja, M., Orzechowski, J. (2008). Inteligencja emocjonalna: fakty, mity, kontrowersje. Warszawa: PWN. 